\title{
CHORWACI A ZJAZD NEOSLAWISTÓW W PRADZE W 1908 ROKU (NA PODSTAWIE ÓWCZESNEJ PRASY CHORWACKIEJ)
}

\section{Damir Agičić}

http://orcid.org/0000-0001-5145-9880

\author{
Uniwersytet w Zagrzebiu (Chorwacja)
}

\section{ABSTRACT \\ THE CROATS AND THE 1908 NEO-SLAVIC CONGRESS IN PRAGUE (ON THE BASIS OF THE CROATIAN PRESS)}

The first congress of the Neo-Slavists took place in Prague, in July 1908. It was the culmination of the movement: the largest and most successful meeting of supporters of Slavic solidarity and mutual cooperation of the Slavic peoples at the beginning of the $20^{\text {th }}$ century. The congress had an anniversary character: it was organized on the occasion of the $60^{\text {th }}$ anniversary of the 1848 Slavic congress in Prague. However, the Prague congress was also a preparatory meeting for the planned great congress and Slavic exhibition in Moscow. The author shows the reactions of the Croatian political public to the preparations for the congress in Prague, as well as to the congress itself.

Keywords: Neo-Slavism, Croats, St. Petersburg meeting, Prague congress in 1908.

Slowa kluczowe: neoslawizm, Chorwaci, spotkanie w Sankt Petersburgu, zjazd w Pradze 1908 r.

Neoslawizm był specyficzną formą współpracy między narodami słowiańskimi na początku XX wieku, przede wszystkim na polu gospodarczym i kulturalnym. Według neoslawistów podstawą w stosunkach pomiędzy narodami słowiańskimi powinno być równouprawnienie, a oczekiwano też pomocy Rosji w walce Słowian przeciwko Niemcom. Mieli oni nadzieję, że nowa Rosja, po rewolucji w 1905 roku, znajdzie sposób oraz siłę, aby odpowiedzieć na takie oczekiwania małych narodów słowiańskich. Ruch neoslawistów miał zwolenników wśród polityków czeskich jedną z głównych postaci tego ruchu był Karel Kramár. Nieco mniej neoslawizm był rozwinięty wśród Bułgarów i Słoweńców, a tylko sporadycznie (i w początkach) wśród Polaków. Wspierali go też niektórzy politycy oraz działacze publiczni, przede 
wszystkim dziennikarze, z Chorwacji-Sławonii (banska Hrvatska) i Dalmacji. Został przyjęty i w niektórych rosyjskich kręgach politycznych i kulturalnych.

Neoslawizm i udział w nim poszczególnych narodów słowiańskich omówiono w kilku monografiach i wielu artykułach naukowych. Do najważniejszych prac należy książka Paula Výšný'ego Neoslavism and the Czechs ${ }^{1}$. Problem ruchu neosłowiańskiego i udział Polaków w nim na początku XX wieku został relatywnie dobrze opracowany w polskiej historiografii, głównie dzięki Pawłowi Wieczorkiewiczowi oraz kilku innym autorom, pośród których należy wspomnieć Henryka Batowskiego i Antoniego Gizę ${ }^{2}$. Ostatni z wymienionych patrzył na ruch neosłowiański przez pryzmat działalności Klubu Słowiańskiego w Krakowie w pierwszym dziesięcioleciu XX wieku. Temat został dobrze opracowany także w czeskiej, słoweńskiej, bułgarskiej oraz rosyjskiej historiografii ${ }^{3}$. W leksykonach i encyklopediach chorwackich nie można znaleźć znaczenia słów: neoslawizm, neoslawista, neoslawistyczny. Tylko w encyklopedii powszechnej, w ramach bardziej ogólnego tekstu o panslawizmie pojawia się krótka wzmianka o neoslawizmie ${ }^{4}$. W historiografii chorwackiej natomiast istnieje zaledwie kilka opracowań na ten temat ${ }^{5}$.

Ruch neosłowiański przestał istnieć już kilka lat po dwóch zjazdach - w Pradze w 1908 roku i w Sofii w 1910 roku - oraz kilku pomniejszych spotkaniach. $\mathrm{Na}$ zjazdach ich uczestnicy omawiali możliwości współpracy kulturalnej i gospodarczej narodów słowiańskich w Austro-Węgrzech i poza ich granicami. Polityczne nieporozumienia i konflikty pomiędzy poszczególnymi narodami słowiańskimi były w tym okresie tak liczne i silne, że dyskusja o sprawach politycznych na zjazdach neosłowiańskich była niepożądana. Uczestnicy ruchu rozumieli, że nie zdołają tych sporów rozwiązać i dlatego raczej ich unikali. Zamiast tego nalegali, aby na zjazdach i innych spotkaniach rozmawiać o gospodarce i kulturze.

Pierwszy zjazd ruchu neoslawistów odbył się w lipcu 1908 roku w Pradze. Na zjazd przyjechali przedstawiciele prawie wszystkich narodów słowiańskich. Przybyli też i polscy przedstawiciele z Królestwa; na czele ich delegacji znajdował się Roman Dmowski, przewodniczący klubu polskiego w Dumie. Kongres praski został

1 P. Višný, Neoslavism and the Czechs, Cambridge 1984.

2 P.P. Wieczorkiewicz, Udziat Polaków w ruchu neosłowiańskim a stosunki polityczne polsko-rosyjskie 1908-1910, „Pamiętnik Słowiański” 1978, t. 28, s. 133-168; H. Batowski, Neoslawizm a stosunki polsko-rosyjskie i polsko-czeskie (1908-1914) [w:] Prace na VI Międzynarodowy Kongres Slawistów w Pradze 1968, t. 1: Historia, [red. nauk. J. Bardach, G. Labuda], Warszawa 1968, Z Polskich Studiów Slawistycznych, seria 3, s. 235-245; A. Giza, Neoslawizm i Polacy, Szczecin 1984.

3 I. Gantar-Godina, Neoslavizem in Slovenci, Ljubljana 1994; Славянское движение XIXХХ веков: Съезды, конгрессы, совещчания, манифесты, обращения, Москва 1998; Е. Лазарова, Славянското движение в България, София 1997.

4 Opća enciklopedija JLZ, sv. 6, Zagreb 1980, s. 291

5 D. Agičić, Hrvati, Poljaci i neoslavizam [w:] Hrvati i Poljaci-narodi daleki i bliski. Zbornik radova sa znanstvenog skupa hrvatskih i poljskih povjesničara, [urednik D. Agičić], Zagreb 2003, s. 55-63; idem, Slavenski kongresi 1910. godine u Sofiji i Hrvati [w:] Българи и хървати през вековете, кн. 2: Материали от конференцията, проведена в София (20-22 май 2001), София 2003, s. 172-184; idem, Između hrvatskog i slavenskog identiteta. Odjeci neoslavističkih kongresa u hrvatskoj javnosti, „Dijalog povjesničara-istoričara” (Zagreb) 2003, 7, s. 107-126. 
poprzedzony spotkaniem przygotowawczym kilku słowiańskich polityków z Austro-Węgier z rosyjskimi neoslawistami w Petersburgu pod koniec maja 1908 roku. Na to spotkanie przygotowawcze delegację poprowadził Karel Kramař. Premier Rosji, Piotr Stołypin, przyjął delegację podczas oficjalnego spotkania. Rozmowy w Petersburgu powinny były wyjaśnić kwestię udziału Polaków na kongresie neosłowiańskim w Pradze, to znaczy przygotować porozumienie rosyjsko-polskie w sprawie normalizacji wzajemnych stosunków.

Czeski historyk Karel Herman uważa, że prawdziwego inicjatora ruchu neosłowiańskiego nie sposób wskazać i w pełni zidentyfikować. Wkrótce po zmianach politycznych wywołanych przez pierwszą rewolucję rosyjską w 1905 roku pojawiło się kilka inicjatyw i sugestii. Jedną z nich była propozycja złożona w 1907 roku przez Aleksandra A. Borzenkę, profesora Uniwersytetu w Odessie ${ }^{6}$. Borzenko zwrócił się do premiera Stołypina i zażądał, aby Rosja wykorzystała swoją siłę na rzecz zjednoczenia Słowian. Wiek XX miał być wiekiem Słowian i Rosji, dlatego nie wolno było ignorować ruchu słowiańskiego - jak podkreślał profesor z Odessy. Obiecał on 100 tysięcy rubli na zorganizowanie kongresu słowiańskiego. W tym czasie była to ogromna suma. Stołypin odpowiedział po dwóch miesiącach, że taki kongres powinien zostać przygotowany, ale można na nim dyskutować tylko o kwestiach kulturalnych, bez poruszania jakichkolwiek kwestii politycznych. Profesor Borzenko zwrócił się również do niektórych polityków słowiańskich w Austro-Węgrzech. Kramár̆ początkowo nie wykazywał dużego zainteresowania propozycją Borzenki, nawet nie odpowiedział rosyjskiemu profesorowi ${ }^{7}$.

Niemniej jednak po pewnym czasie pojawiła się propozycja zwołania kongresu słowiańskiego w Pradze. W maju 1907 roku zespół redakcyjny czeskiego czasopisma „Maj” zaproponował Czeskiej Radzie Narodowej (Národní rada česka) zorganizowanie nowego kongresu słowiańskiego z okazji 60. rocznicy Kongresu Słowiańskiego w Pradze z 1848 roku. Rada przyjęła tę propozycję i już 1 czerwca 1907 roku zażądała opinii posłów słowiańskich w Radzie Państwa w Wiedniu. Powstała komisja przygotowawcza zjazdu pod przewodnictwem Josefa Herolda i Vratislava Černý’ego. Do października 1907 roku, w porozumieniu z czeskimi ugrupowaniami politycznymi, decyzja o przygotowaniu zjazdu została potwierdzona. Półtora miesiąca później, 28 listopada 1907 roku, Czeska Rada Narodowa przesłała zapytanie o gotowość uczestnictwa w kongresie słowiańskim do wszystkich krajów słowiańskich poza Austro-Węgrami ${ }^{8}$. To zapytanie spotkało się z dużym zainteresowaniem ${ }^{9}$.

Po tym, jak w 1907 roku profesor Uniwersytetu w Odessie Aleksandr Borzenko obiecał ofiarować znaczącą sumę na organizacje dorocznych kongresów przedstawicieli narodów słowiańskich, rozpoczęły się poważniejsze przygotowania do pierwszego takiego zjazdu. Wiadomość o propozycji Borzenki dotarła do Wiednia za pośrednictwem posła w Radzie Państwa Dmitrija Markowa, a z jego inicjatywy

6 K. Herman, Novoslovanstvi a česká buržoasie [w:] Kapitolý z dějin vzájemných vztahů národi̊ ČSR a SSSR, Prague 1958, s. 271-272.

7 Ibidem, s. 272-273.

8 Ibidem, s. 272.

9 Ibidem. 
doszło do spotkania przedstawicieli słowiańskich klubów parlamentarnych. W lutym 1908 roku przedstawiciele Słowian w Radzie Państwa odpowiedzieli Borzence, że na początku marca odbędzie się spotkanie, na którym obecni będą również polscy parlamentarzyści, więc zapadnie decyzja o tym, czy polscy przedstawiciele wezmą udział w zjeździe, jak również o terminie i miejscu tego kongresu ${ }^{10}$. Gdy polscy przedstawiciele wkrótce podjęli pozytywną decyzję o udziale w kongresie słowiańskim, rosyjska gazeta „Nowoje wremja” pochwaliła tę decyzję, a zagrzebski „Obzor” przedrukował tę informację z wielką satysfakcją ${ }^{11}$.

Przewodniczącym rady złożonej z przedstawicieli klubów słowiańskich w Radzie Państwa, której zadaniem była dyskusja o propozycji zwoływania kongresu słowiańskiego, został wybitny polityk słoweński, burmistrz Lublany Ivan Hribar. W swych pamiętnikach podkreśla on, że już na pierwszym spotkaniu podjęto decyzję, iż „byłoby ważne, aby przedstawiciele wszystkich narodów słowiańskich w Radzie Państwa wstąpili jawnie wspólnie i zademonstrowali, że słowiańska solidarność nie jest pustą frazą ani utopią"12, w związku z czym zdecydowali zaprosić wszystkie kluby, aby wysłały swoich przedstawicieli. Tak się też stało, a na drugim spotkaniu pojawiło się między innymi sześciu Czechów, Kramář, dziewięciu Słowian Południowych, trzech Polaków i pięciu „Rusów” (to jest Rusinów). Wiceprzewodniczącymi mianowani zostali Karel Kramář i Mykoła Hlibowyćkyj, a sekretarzem Ante Tresić Pavičić. Na tym spotkaniu Kramář wygłosił bardzo pragmatyczne przemówienie, w którym między innymi podkreślił, że kongres słowiański należy dobrze przygotować, tak aby stosunki między narodami słowiańskimi ukształtować w taki sposób, żeby obywatele nie działali przeciwko sobie. Zainicjowanemu ruchowi nadał też nazwę:

Na wielki wszechsłowiański kongres musimy przybyć z nowym wielkim programem. Nazwijmy go programem nowosłowiańskim. Neoslawizm niech opiera się na dogmacie: równość, wolność i braterstwo wszystkich narodów słowiańskich ${ }^{13}$ [wyróżnienie oryg.].

Od tego momentu odbywano regularne cosobotnie spotkania w mieszkaniu Kramářa. O przygotowaniach w ciągu zimy i wiosny 1908 roku od czasu do czasu pisano w prasie zarówno w Austro-Węgrzech, jak i w Rosji. Pisząc o przygotowaniach zainicjowanych przez kluby parlamentarne w Radzie Państwa, zagrzebski „Obzor” podkreślał, że organizacja większej liczby kongresów słowiańskich nie byłaby wskazana, ale brak ich organizacji również byłby zły. Chorwacka gazeta opowiadała się zatem za umiarkowaniem w tym zakresie ${ }^{14}$.

Do Sankt Petersburga pojechała pod koniec maja 1908 roku delegacja słowiańskich polityków z Austro-Węgier. Na rozmowy z rosyjskimi neoslawistami udali się Kramář, Hlibovicki i Hribar. Mieli ustalić konkretne warunki organizacji kongresu słowiańskiego. Gazeta „Hrvatska riječ” z Šibenika pisała, że „Kramarž, Hribar, Hlibowyćkyj są tam jak na nieprzerwanym święcie. Wszędzie przyjmowani z wielkim

10 Panslavistički kongres, „Narodna obrana”, 20 II 1908.

11 Nova faza u pitanju slavenskog kongresa, „Obzor”, 20 III 1908.

12 I. Hribar, Moji spomini, 1. del: Od 1853. do 1910. leta, Ljubljana 1928, s. 231.

13 Ibidem, s. 232.

14 Osnova o sazivu sveslovjenskih kongresa, „Obzor”, 8 I 1908. 
entuzjazmem. Ich przemówienia spotykają się z wielkim zachwytem"15. Przed wyjazdem do Petersburga korespondent gazety „Obzor” z Wiednia przeprowadził wywiad z posłem Hlibowyćkym. Ten zaś twierdził, że głównym warunkiem zwołania kongresu jest przyciągnięcie na niego Polaków z trzech krajów (Austro-Węgier, Rosji i Niemiec), jak również przestrzeganie zasady, że kongres pozostaje poza wpływami kręgów oficjalnych, czy to rosyjskich czy austriackich:

Musimy wziąć pod uwagę okoliczności, że z jednej strony Rosjanom i Polakom z Rosji byłoby nieprzyjemnie, gdybyśmy chcieli kongresowi nadać cechy ,austrianizmu”, a nam nie byłoby przyjemnie, gdyby się kongresowi nadało piętno panslawizmu ${ }^{16}$.

Hlibowyćkyj podkreślał, że organizatorzy stawiają sobie cele czysto kulturalne, bez żadnych konotacji politycznych. Uważał, że czas panslawizmu minął, tak samo jak i czas tzw. idealnego „słowianofilstwa”, pełnego patetycznych frazesów:

Teraz nadchodzi nowy czas, czas realnej pracy wszystkich narodów słowiańskich, i to nie każdego samego dla siebie, ale dla całej rodziny słowiańskiej, aby ją uratować przed Drangom [Drang nach Osten - parcie na wschód] elementów obcych ${ }^{17}$.

Hlibowyćkyj podkreślił również, że można zauważyć znaki zbliżenia Polaków i Rosjan, których wzajemne stosunki są rzeczywiście bardzo trudne. Właśnie w tym widział główne zadanie kongresu - aby pomóc w rozwiązywaniu kwestii spornych i „leczeniu ran”. Na końcu wywiadu proponował, aby jak najszybciej zakończyć kryzys rządowy w Chorwacji ${ }^{18}$. Od marca 1908 r. bowiem parlament chorwacki, Sabor, był rozwiązany i ban Pavao Rauch rządził samodzielnie. Temu kryzysowi politycznemu towarzyszył również strajk studentów, który zaczął się, gdy ban Rauch z przyczyn politycznych odesłał na emeryturę dziekana Wydzialu Filozofycznego, prof. Đurę Šurmina, oraz profesora historii powszechnej, Gavrę Manojlovicia.

W tym samym numerze „Obzoru” znajdujemy również duże fragmenty artykułu chorwackiego emigranta w Rosji, Krunoslava Heruca, przedrukowane z gazety „Gołos prawdy” ${ }^{19}$. Heruc z jednej strony pisał w nim o korzyściach, jakie może mieć jego nowa ojczyzna Rosja ze zbliżenia ze Słowianami. Uważał, że kongres słowiański powinien być dobrze przygotowany, tymczasem ze względu na to, że komitet organizacyjny działał tylko w Wiedniu, oceniał te przygotowania nie najlepiej. Z drugiej strony, jak podkreślał Heruc, brakowało szczerości w stosunku do kwestii słowiańskiej, albo przynajmniej on jej nie widział. Zarzucał, że o słowiańskości rozmyśla się tylko w kontekście problemów i nieszczęść narodów słowiańskich. Wśród osób wspierających ideę organizacji kongresu słowiańskiego brakowało naukowców, artystów i działaczy publicznych. W ocenie Heruca w przygotowania na razie włączeni byli tylko politycy, a oni nie umieliby zdystansować się od tematów politycznych, co ostatecznie mogłoby doprowadzić do podziałów. Te prorocze przepowiednie chorwackiego emigranta spełniły się w pełni później.

15 Naše brzojavke, „Hrvatska riječ”, 30 VI 1908.

16 Sveslavenski kongres, „Obzor”, 24 VI 1908.

17 Ibidem.

18 Ibidem.

19 Ibidem. 
W związku ze spotkaniem w Petersburgu swój pesymizm wyraził również redaktor „Slovanskiego přehledu” Adolf Černý, który nie wierzył w możliwość porozumienia z Rosjanami, a w szczególności że z Rosjanami mogą porozumieć się Polacy.

Ivan Hribar w swoich wspomnieniach opisywał serdeczne powitanie w Sankt Petersburgu ${ }^{20}$. W czasie spotkania zaprosił rosyjskich dziennikarzy na kongres dziennikarzy w Lublanie, który właśnie przygotowywano ${ }^{21}$. W uroczystym obiedzie wystawionym na cześć gości wzięło udział ponad 250 rosyjskich polityków i dziennikarzy. Wznoszono toasty ku czci cesarzy Franciszka Józefa I i Mikołaja II, przewodniczącego Dumy Aleksieja Chomiakowa i innych. Jedna z chorwackich gazet sarkastycznie skomentowała to wydarzenie: „Jak widać, trwają przygotowania do kongresu - jedzą, piją i gadają!"’22. Na tym bankiecie Kramáŕ podkreślał, że żaden z narodów nie pragnie zmiany granic państwowych, lecz ,zjednoczenia rasy słowiańskiej na bazie kultury i braterstwa duchowego”. Jak donosił „Riječki novi list”, w tamtym momencie w Sankt Petersburgu czeski polityk uważał, że większość Rosjan stawia sobie te same cele ${ }^{23}$.

Po powrocie z Rosji Kramář, Hlibowyćkyj i Hribar zorganizowali w Wiedniu konferencję prasową, w czasie której zdali relację ze swej podróży. Nie brakowało im optymizmu, gdy chodziło o rozwój stosunków między Słowianami, w szczególności stosunków polsko-rosyjskich, ponieważ Polacy zgodzili się na udział w kongresie wszechsłowiańskim, który miał się wkrótce odbyć w Pradze ${ }^{24}$. Kramář poczuł się obrażony oskarżeniami, jakoby miał prosić o audiencję u cara. Twierdził, że to nieprawda i oskarżenia o zdradę są bezpodstawne, ponieważ o jego podróży poinformowany był zarówno minister spraw zagranicznych Austro-Węgier Alois Lexa von Aerenthal, jak i cała austriacka opinia publiczna, informowana na bieżąco o całym pobycie słowiańskiej delegacji z Austrii ${ }^{25}$.

Chorwacka oficjalna gazeta „Narodne novine” bardzo skąpo informowała o rozmowach $\mathrm{w}$ Petersburgu ${ }^{26}$. Podobnie było, o dziwo, w przypadku postępowej gazety „Pokret”"27. Również konserwatywny list „Hrvatsko pravo” nie poświęcał zbyt wiele miejsca pobytowi trzech słowiańskich posłów z Wiednia w Petersburgu. Opublikowano tylko krótkie informacje, a jedyny obszerniejszy tekst umieszczony został pod wiele mówiącym tytułem „Sveslavenska komedija”. W tekście tym przywoływano to, co pisała krakowska „Nowa Reforma”, w której w imieniu Polaków zdecydowanie odrzucano myśl o panslawizmie w jakiejkolwiek formie:

20 I. Hribar, op. cit., s. 234.

21 Slavenski pokret, „Riečki novi list”, 4 VI 1908. Kongres odbył się w Lublanie we IX 1908 r.

22 Sveslavenski kongres, „Hrvatska sloboda”, 2 VII 1908.

23 Kramarž, Hribar i Hlibovicki u Petrogradu, „Riečki novi list”, 29 V 1908.

24 Provedba slavenske uzajamnosti, ,Narodna obrana”, 5 VII 1908.

${ }_{25}$ Izjava dra Kramarža, ,Narodna obrana”, 9 VII 1908.

26 Zast. dr. Kramarž i drugovi u Petrogradu, „Narodne novine”, 29 VI 1908.

27 Slavenski zastupnici u Petrogradu, „Pokret”, 30 VI 1908. 
Czesi i Słowianie Południowi, którym daleko do Rosji mogą sobie pozwolić na zabawę w panslawizm, a tym sypią piasek w oczy Niemców. Ale my Polacy, których kultura jest bezpośrednio zagrożona ze strony rosyjskiego barbarzyństwa, nie jesteśmy w tym szczęśliwym położeniu ${ }^{28}$.

Nie trzeba szczególnie podkreślać, że gazeta ta, organ prawicowej nacjonalistycznej Czystej Partii Prawa (Čista stranka prava) pod kierownictwem Josipa Franka, Tak zwani frankovci, zgadzał się w pełni z tym stanowiskiem.

Kongres neoslawistyczny w Pradze zorganizowany w lipcu 1908 roku przebiegł w serdecznej i podniosłej atmosferze. Głównymi tematami dyskusji była potrzeba założenia banku słowiańskiego i przygotowania do wielkiej wystawy słowiańskiej. Oprócz tego wśród tematów znalazły się słowiańska turystyka, ruch sokolski, kwestia dziennikarzy czy księgarń. Jednogłośnie przyjęto rezolucje o tych tematach oraz wybrano członków komitetu, który miał się zająć ich realizacją, jak również przygotowaniami do założenia banku i organizacji wystawy. W kongresie udział wzięło tylko kilku przedstawicieli z Chorwacji: Ante Tresić Pavičić, Ljuba Babić, Božo Vinković, Ivan Lorković, Stjepan Radić i Dušan Popović ${ }^{29}$. Najliczniejsza była - zgodnie z oczekiwaniami - delegacja czeska. Oprócz Czechów na kongresie obecnych było wielu przedstawicieli rosyjskich reprezentujących przede wszystkim prawe centrum sceny politycznej, co znaczy, że byli to w zasadzie przedstawiciele starej idei panslawistycznej ${ }^{30}$. Stosunkowo liczna była delegacja polska, której przewodził Roman Dmowski ${ }^{31}$, przywódca Narodowej Demokracji. Politycy tej opcji uważali, że niebezpieczeństwo niemieckie dla polskich interesów narodowych jest groźniejsze od rosyjskiego, w związku z czym opowiadali się za ideą współpracy z Rosjanami. Ze Słoweńców w przygotowaniach do kongresu szczególnie się wykazał Ivan Hribar, burmistrz Lublany i poseł do Rady Państwa. Delegacji bułgarskiej przewodził Stefan Sawow Bobczew, a serbskiej Giga Geršić. W kongresie nie wzięli udziału przedstawiciele Polaków z zaboru niemieckiego ani przedstawiciele galicyjskich Rusinów (Ukraińców - obecni byli tylko starorusini - rusofilscy politycy na czele z Mykołą Hlibowyćkym) ani delegaci Serbołużyczan. Nie było osobnej delegacji słowackiej.

Kongres w Pradze rozpoczął się 12 lipca 1908 roku i potrwał tydzień. Otworzył go Karel Kramář, pozdrawiając serdecznie przybyłych gości i wskazując na cele ruchu

28 Sveslavenska komedija, „Hrvatsko pravo”, 4 VII 1908.

29 Sveslavenski sastanak u Pragu, „Obzor”, 16 VIII 1908; I. Gantar-Godina, op. cit., s. 120. Ljuba Babić (1854-1935) - prawnik, polityk i pisarz, znany też pod pseudonymem Ksaver Šandor Gjalski; poseł Koalicji Chorwacko-Serbskiej w Saborze (w 1906 r.); jeden z czołowych przedstawicieli chorwackiego realizmu. Ante Tresić Pavičić (1867-1949) - polityk, publicysta i pisarz, poseł w Radzie Państwa od 1906 r.; w początkach kariery politycznej w Partii Prawa, a póżniej zwolennik jugosławizmu. Božo Vinković (1862-1924) - prawnik i polityk, publicysta, na początku w Partii Prawa, od 1906 r. zwolennik Koalicji Chorwacko-Serbskiej, redaktor gazety „Narodni glas”. Ivan Lork ović (1876-1926) - publicysta i polityk, redaktor gazety „Narodna obrana” w Osijeku, jeden z założycieli Chorwackiej Partii Postępowej (w 1904 r.), poseł w Saborze (w 1906 r.). Stjepan Radić (1871-1928) - polityk, jeden z założycieli Chorwackiej Ludowej Partii Chłopskiej (w 1904 r.), poseł w Saborze, odgrywał bardzo ważną rolę w Królestwie Serbów, Chorwatów i Słoweńców. Dušan Popović (1877-1958), prawnik i polityk serbskiego pochodzenia, poseł Koalicji Chorwatsko-Serbskiej w Saborze (w 1906 r.).

30 I. Gantar-Godina, op. cit., s. 120.

31 K. Kawalec, Roman Dmowski 1864-1939, Wrocław-Warszawa-Kraków 2002, s. 102 i n. 
neoslawistycznego: równość wszystkich narodów słowiańskich, rozwój gospodarczy i kulturalny Słowian, ich braterstwo nie tylko w słowach, ale i w czynach ${ }^{32}$. Po Kramářu przemawiał przywódca delegacji rosyjskiej Wasilij Michajłowicz Krasowskij, który wypowiedział wiele pochwał pod adresem Pragi jako „nośnika kultury słowiańskiej jako przedniej straży cywilizacji słowiańskiej" ${ }^{33}$ oraz odrzucił oskarżenia kierowane pod adresem Rosji, jakoby była przeszkodą w organizacji kongresu. „Rosja pragnie swobodnego życia, postępu i rozwoju wszystkich narodów słowiańskich" - podkreślał ${ }^{34}$. Wsparł go członek Dumy Wasilij Aleksiejewicz Maklakow: „My, gdy mówimy o wzajemności wszechsłowiańskiej, wychodzimy z założenia, że bez wolności i równości nie może być braterstwa między narodami słowiańskimi”"35. Następnie w imieniu delegacji polskiej przemawiał Dmowski, który miał stwierdzić, że proces rozwiązywania kwestii spornych między politykami polskimi i rosyjskimi już się rozpoczął i istnieje nadzieja, że zakończy się on sukcesem. Przemawiali również przedstawiciele innych narodów, które brały udział w kongresie.

Chorwacki pisarz i polityk Ante Tresić Pavičić na uroczystości otwarcia kongresu wygłosił płomienne przemówienie o słowiańskości i zgodzie Serbów i Chorwatów:

Przynoszę wam bracia Słowianie pozdrowienia od Chorwatów, a gdyby przede mną nie przemawiał serbski mówca - powiedziałbym i od Serbów. Dlatego, że gdy przemawia Chorwat jakby przemawiał Serb, a gdy przemawia Serb to jakby przemawiał Chorwat ${ }^{36}$.

Stwierdził dalej, że Chorwaci i Serbowie zakończyli swoje wcześniejsze spory. Od kongresu i jego uczestników oczekiwał, żeby pracowali „dla dobra rodziny słowiańskiej” - zawsze i wszędzie, a jako swe największe pragnienie wymienił to, aby po zakończeniu kongresu mógł być pewien świetlanej przyszłości Słowiańszczyzny $^{37}$. Wystąpienie Tresicia w Chorwacji wywołało ostrą reakcję redakcji gazety prawaszy „Hrvatska sloboda”, która mu odmówiła prawa wypowiadania się w imieniu narodu chorwackiego. Twierdzono, że w ogromnej większości Chorwaci nie wiedzą prawie nic o kongresie, a nikt nie upoważnił Tresicia, aby występował w imieniu całego narodu ${ }^{38}$. Była to gazeta, która zasadniczo sprzeciwiała się organizacji kongresu słowiańskiego.

Uczestnicy kongresu mogli przemawiać każdy w swoim języku. Przyjęto regulamin obrad, według którego o konkretnych kwestiach można było mówić tylko dwukrotnie $^{39}$. Żywa polemika rozwinęła się wokół pytania, czy dziennikarze powinni uczestniczyć w posiedzeniach. Ostatecznie przyjęto, że można wydać konkretne pozwolenia tylko tym dziennikarzom, których wiarygodność potwierdzą członkowie poszczególnych delegacji. Dziennikarze zaś musieli się zobowiązać, że będą

\footnotetext{
32 Sveslavenski sastanak u Pragu, „Obzor”, 15 VIII 1908.

Ibidem.

Sveslavenski sastanak u Pragu, „Obzor”, 16 VIII 1908.

Ibidem.

Ibidem.

Ibidem; Sveslavenski kongres u Pragu, „Pokret”, 15 VIII 1908.

Also sprach dr. Tresić-Pavičić, „Hrvatska sloboda”, 17 VIII 1908.

39 Sveslavenski sastanak u Pragu, „Obzor”, 17 VIII 1908.
} 
relacjonować lojalnie i wiarygodnie o obradach kongresu i że będą postępować zgodnie z poleceniami prezydium obrad ${ }^{40}$.

Owacjami przyjęto decyzję przedstawicieli narodów południowosłowiańskich Bułgarów, Serbów, Chorwatów i Słoweńców o tym, że wszystkie kwestie rozstrzygać będą wspólnie. Jeszcze większy entuzjazm wywołała polsko-rosyjska zgoda, która zapanowała w czasie wystąpień i dyskusji na posiedzeniach oraz na bankietach, kiedy to wybrzmiała w postaci wznoszonych toastów ${ }^{41}$. Ogólnie w czasie kongresu nie było większych rozbieżności zdań. Jak już wspomniano, jednogłośnie przyjęto rezolucje na tematy, o których dyskutowano, oraz wybrano komitet wykonawczy, który miał się zająć ich realizacją.

„Obzor” zadał pytanie, czy udział chorwackich przedstawicieli miał sens, jaki był przewidziany w praskim kongresie. Gdyby chodziło o starą formę panslawizmu, według którego Rosja miała „połknąć” pozostałe narody słowiańskie, wtedy byłoby bez znaczenia, jak by się takie idee manifestowały w Chorwacji - pisał „Obzor”. Ale tutaj mowa była o nowej formie idei słowiańskiej, w której nie chodziło o stopienie wszystkich Słowian w jeden naród - rosyjski, lecz przede wszystkim o ochronę całej Słowiańszczyzny:

Ta wzajemność słowiańska nie uniformuje narodów słowiańskich w sensie politycznym i kulturalnym, lecz skierowana jest ku ich indywidualizacji, ku pomocy w budowie ich bytu ${ }^{42}$.

W związku z tym nie jest wszystko jedno, jak Chorwaci są na takim spotkaniu reprezentowani. A uczestnicy kongresu w Pradze nie byli wystarczająco reprezentatywni ani jeśli chodzi o regiony, z których pochodzili (byli to głównie przedstawiciele Chorwacji właściwej), ani jeśli chodzi o przynależność do partii politycznych - podkreślał „Obzor”43.

W podobnym duchu pisał „Pokret”"44, podkreślając, że forma, w której ostatnio odnowił się ruch słowiański, jest odmienna od niegdysiejszego rosyjskiego panslawizmu, ponieważ podstawą nowego słowianofilstwa jest równouprawnienie wszystkich narodów słowiańskich. Gazeta liberalnej Chorwackiej Ludowej Partii Postępu (Hrvatska pučka napredna stranka) cytowała słowa księcia Jewgienija Trubeckiego o tym, że Rosja musi zerwać ze swą historyczną sprzecznością, to jest że przedstawia się jako wyzwolicielka Słowian na Bałkanach, a równocześnie ciemięży słowiańskie narody; że musi stać się państwem słowiańskim nie tylko na zewnątrz, ale i w swoich granicach. Prasa Chorwackiej Partii Postępowej („Pokret”) uważała, że nowe okoliczności polityczne w Europie idą na rękę polityce słowiańskiej. W szczególności niemieckie „parcie na wschód” powinno połączyć wszystkich Słowian.

W momencie kiedy kongres neoslawistyczny już się rozpoczął, „Obzor” wyjaśniał chorwackiej opinii publicznej, jakie są zamiary tego zjazdu:

\footnotetext{
40 Ibidem.

${ }^{41}$ Sveslavenski kongres, „Pokret”, 17 VIII 1908.

42 Sveslavenski sastanak u Pragu, „Obzor”, 17 VIII 1908.

43 Hrvatski i sveslavenski kongres, „Obzor”, 8 VIII 1908.

${ }^{44}$ Kongres slavenskih delegata, „Pokret”, 7 VIII 1908.
} 
[...] aby niezależnie od pożałowania godnych istniejących konfliktów pomiędzy poszczególnymi narodami słowiańskimi zdefiniować i ustalić na przyszłość jeden wspólny program kulturalny, jedną dyrektywę bez względu na partie pośród narodów słowiańskich [...], stworzyć jedną słowiańską kulturę, aby zachowane zostały przyrodzone elementy kultury słowiańskiej i zabezpieczone przed obcymi wpływami i ostatecznie, aby poprzez kulturę rozwiązać istniejące problemy polityczne lub partyjne pomiędzy poszczególnymi słowiańskimi plemionami i w nich samych $^{45}$.

Wśród gazet chorwackich obszerniejsze relacje z praskiego kongresu neoslawistycznego opublikowały gazety „Obzor” i „Pokret”. Przebieg kongresu był szczegółowo śledzony także przez tygodnik „Dom”. Ta gazeta Chorwackiej Ludowej Partii Chłopskiej (Hrvatska pučka seljačka stranka) pisała o kongresie bardzo pozytywnie. Autor szeregu tekstów, sam przewodniczący partii Stjepan Radić, podkreślał wagę zgody pomiędzy Polakami i Rosjanami. Pisał, że „nawet Rosja oficjalnie stoi na stanowisku słowiańskiego braterstwa", a jako najbardziej zasłużoną osobę wskazywał Kramářa. W takich okolicznościach nastąpił czas zgody słowiańskiej również dla Chorwatów, jak twierdził przywódca chłopów: ,musimy teraz pilnie orać i pracowicie siać ziarno słowiańskiej polityki chłopskiej" ${ }^{46}$. W przededniu samego kongresu „Dom” opublikował obszerny tekst Radicia, w którym podkreślał wagę spotkania w Pradze polityków, a nie tylko - jak to bywało na wcześniejszych słowiańskich zlotach -studentów, młodzieży, pisarzy i dziennikarzy. Większą wagę praskiego spotkania widział już w tym, że miało się dyskutować na nim według z góry przygotowanego regulaminu obrad o tym, co konkretnie można uczynić na korzyść słowiańskiej kultury i gospodarki ${ }^{47}$. Rezultaty kongresu Radić ocenił jako sukces, a szczególnie zwrócił uwagę na trzy kwestie: delegaci rosyjscy ciągle podkreślali ważność Czechów dla Słowiańszczyzny, zwłaszcza na polu oświaty, Rosjanie i Polacy nie pokłócili się, a w kongresie uczestniczyli przedstawiciele narodów słowiańskich niezależnie od swoich rządów. Według Radicia kongres w Pradze znaczący był również dla Chorwatów, gdyż umożliwił pokazanie zasług chorwackich w przeszłości na polu szerzenia idei słowiańskiej. Oczekiwał, że po kongresie będzie łatwiej zrealizować zadanie programowe Chorwackiej Ludowej Partii Chłopskiej na polu szerzenia braterstwa Słowian - sprzeciwić mu się będą mogli tylko zupełni ignoranci, a uważał, że są oni w Chorwacji w mniejszości ${ }^{48}$.

W Chorwacji jednak było wielu przeciwników neoslawizmu czy też ,szerzenia braterstwa słowiańskiego" wśród elit politycznych i wśród przywódców partii. Część gazet po prostu przemilczała wydarzenia w Pradze, a niektóre opublikowały ostre krytyczne teksty. Na przykład „Ustavnost” - gazeta Levina Raucha - wydrukowała tylko kilka krótkich wiadomości, a także obszerny tekst krytyczny, zatytułowany Sveslavenska komedija ${ }^{49}$. Chociaż tekst został zatytułowany tak, by sugerować, że dotyczy kongresu neoslawistycznego, w rzeczywistości mówił o kongresie

\footnotetext{
45 II. sveslavenski sastanak u Pragu, „Obzor”, 14 VIII 1908.

46 S. Radić, Potpuno slavensko bratimstvo u punom horu, „Dom”, 3 VII 1908.

47 Idem, Velika slavenska djela, „Dom”, 8 VIII 1908.

48 Idem, Slavenski narodni sabor u Zlatnom Pragu, „Dom”, 22 VIII 1908.

49 Sveslavenska komedija, „Ustavnost”, 13 VIII 1908.
} 
postępowych studentów słowiańskich, który odbył się w Pradze pod koniec czerwca 1908 roku i nie miał nic wspólnego z neoslawistami! „Narodne novine” nie opublikowały żadnych artykułów oprócz przedruku krótkich wzmianek telegraficznych. W podobny sposób postąpiło „Hrvatsko pravo” - dla prawaszy frankowców (frankowcy - zwolennicy odłamu Partii Prawa, to jest Czystej Partii Prawa, którą od 1895 roku kierował adwokat Josip Frank) ważne było poinformować swoich czytelników, że w Warszawie doszło do demonstracji przeciwko udziałowi Dmowskiego w kongresie w Pradze, oraz ośmieszyć chorwackich polityków, którzy się na niego udali, nazywając ich naszymi ,wielkimi politykami" ${ }^{50}$.

Wkrótce po tym, jak słowiańscy delegaci rozjechali się do domów, doszło do aneksji Bośni i Hercegowiny i głębokiego kryzysu w stosunkach pomiędzy Austro-Węgrami i Rosją. Jeden z najważniejszych celów, jakie przed sobą stawiali zwolennicy neoslawizmu - polityczne zbliżenie między tymi dwoma państwami w celu uzyskania przeciwwagi dla parcia Niemiec - stał się w zasadzie nieosiągalny. Krótko po tym, jak neoslawizm pojawił się na scenie politycznej, zapadł on w kryzys, z którego - jak się później okazało - już nie mógł wyjść.

Zorganizowano jednak jeszcze jeden zjazd neoslawistów - drugi przygotowawczy kongres w Sofii. Odbył się w dniach 7-10 lipca 1910 roku pod przewodnictwem Stefana Sawowa Bobczewa, a honorowym przewodniczącym został Karel Kramár. Tym jednak razem skład delegacji nie był tak reprezentatywny jak to miało miejsce na pierwszym kongresie. Zabrakło bowiem przedstawicieli Polaków, a poza tym w drugim kongresie nie wzięli udziału również przedstawiciele Białorusinów, większości galicyjskich Rusinów ani Serbołużyczan. Chorwaci i Serbowie byli reprezentowani w składzie wspólnej delegacji, ale nie było w niej nikogo z Chorwacji właściwej, choć zaproszono ponad dwadzieścia osób! ${ }^{51} \mathrm{~W}$ skład tej chorwacko-serbskiej delegacji wchodziło tylko dwóch posłów do Rady Państwa: Ante Tresić Pavičić i Matko Mandić. Profesor gimnazjum Ivan Žic z Chorwacji był na liście gości ,honorowych" 52 .

Kongresy słowiańskie i polemiki, które one wywoływały, często były wykorzystywane w wewnętrznych sporach politycznych w Chorwacji. Neoslawistycznym ideom szczególnie nie byli przychylni socjaliści, ale z zupełnie innych względów niż prawasze frankowcy oraz grupa klerykalna skupiona wokół gazety „Hrvatstvo”. Podczas gdy frankowcy i klerykałowie występowali z pozycji nacjonalistycznych i katolicko-prozelitycznych, socjaliści w neoslawizmie widzieli narzędzie realizacji kontrrewolucyjnych celów w Rosji, rosyjskiej polityki imperialnej i „kapitalistycznych interesów" słowiańskiej burżuazji Rosji i Austro-Węgier ${ }^{53}$.

Kongres w Sofii z 1910 roku stał się momentem przełomowym w rozwoju ruchu neoslawistycznego. Po nim ruch ten w zasadzie przestał istnieć. Neoslawiści de facto zrezygnowali ze swych ambitnych projektów i z założenia słowiańskiego

50 Izmirenje Rusa i Poljaka, „Hrvatsko pravo”, 17 VIII 1908.

51 P. Vyšný, op. cit., s. 191-192; Втори подготовителен славянски събор в София, София 1911, s. 9-13.

52 втори подготовителен славянски събор..., s. 23-24.

53 Sveslavenski kongres u Sofiji i socijalna demokracija, „Slobodna riječ”, 9 VIII 1910. 
banku oraz z organizacji wielkiej słowiańskiej wystawy, a także z szeregu innych instytucjonalnych form współpracy Słowian. W ciągu następnych dwóch lat odbyły się jeszcze dwa kongresy słowiańskich dziennikarzy (w Belgradzie i w Pradze), a potem ruch neoslawistycznych dziennikarzy też całkowicie zamarł. Próba wiązania narodów słowiańskich na polu kultury i gospodarki pomimo nadszarpniętych stosunków politycznych pomiędzy niektórymi z nich, zakończyła się klęską, nie dała i nie mogła dać żadnych rezultatów. Na kongresach wypowiadano wiele życzeń, ale były one najczęściej niemożliwe do zrealizowania w kontekście rzeczywistej sytuacji politycznej, a cały ruch, oparty przede wszystkim na pokrewieństwie językowym - był z góry skazany na niepowodzenie.

Błędne było wstępne założenie neoslawistów, że możliwe jest zbliżenie kulturalne i gospodarcze pomimo istniejących konfliktów politycznych pomiędzy narodami słowiańskimi. Konflikt interesów narodowych pomiędzy Rosjanami i Polakami, pomiędzy Polakami i Rusinami (Ukraińcami) w Galicji, Ukraińcami w Imperium Rosyjskim i Rosjanami, Chorwatami i Serbami czy Serbami i Bułgarami był bardzo silny, a interesy polityczne przeciwstawne. Jedynym łącznikiem pomiędzy tymi narodami była przynależność do tej samej grupy językowej. Najbardziej zainteresowani neoslawizmem byli Czesi. Wynikało to $z$ tego, że mieli ku temu najmocniejsze powody: z jednej strony uważali rynek rosyjski i rynki innych krajów słowiańskich za interesujący teren swych inwestycji kapitałowych i za naturalny rynek zbytu swoich towarów przemysłowych, z drugiej zaś strony w Rosjanach i pozostałych Słowianach widzieli sojuszników w ewentualnym konflikcie z Niemcami.

W Chorwacji zainteresowanie neoslawizmem nie było zbyt mocne, chociaż na zjazdach uczestniczyli niektórzy znani działacze polityczni, jak Ksaver Šandor Gjalski, Ante Tresić Pavičić oraz Stjepan Radić. Jeśli chodzi o stosunek do ruchu neoslawistycznego, w chorwackiej polityce obecne były dwa kierunki: popierali go, a w pewnej mierze brali w nim udział członkowie partii należących do Koalicji Chorwacko-Serbskiej (utworzonej z chorwackich i serbskich stronnictw politycznych działających w Chorwacji w 1905 r.), a ostro mu się sprzeciwiali prawasze frankowcy, klerykalne grupy skupione wokół gazety „Hrvatstvo” i socjaldemokraci.

Przettumaczyła Magdalena Najbar-Agičić

\section{BIBLIOGRAFIA}

\section{Źródła}

\section{Źródła drukowane}

Hribar I., Moji spomini, 1. del: Od 1853. do 1910. leta, Ljubljana 1928.

Втори подготовителен славянски събор в София, София 1911. 
Prasa

„Dom” 1908.

„Hrvatska riječ” 1908.

„Hrvatska sloboda” 1908.

„Hrvatsko pravo” 1908.

„Narodna obrana” 1908.

„Obzor” 1908.

„Pokret” 1908.

„Riečki novi list” 1908.

„Slobodna riječ” 1910.

„Ustavnost” 1908.

\section{Opracowania}

Agičić D., Hrvati, Poljaci i neoslavizam [w:] Hrvati i Poljaci-narodi daleki i bliski. Zbornik radova sa znanstvenog skupa hrvatskih i poljskih povjesničara [urednik D. Agičić], Zagreb 2003, s. 55-63.

Agičić D., Između hrvatskog $i$ slavenskog identiteta. Odjeci neoslavističkih kongresa u hrvatskoj javnosti, „Dijalog povjesničara-istoričara” (Zagreb) 2003, 7, s. 107-126.

Agičić D., Slavenski kongresi 1910. godine u Sofiji i Hrvati [w:] Българи и хървати през вековете, кн. 2: Материали от конференцията, проведена в София (20-22 май 2001), София 2003, s. 172-184.

Batowski H., Neoslawizm a stosunki polsko-rosyjskie i polsko-czeskie (1908-1914) [w:] Prace na VI Międzynarodowy Kongres Slawistów w Pradze 1968, t. 1: Historia, [red. nauk. J. Bardach, G. Labuda], Warszawa 1968, Z Polskich Studiów Slawistycznych, seria 3, s. 235-245.

Gantar-Godina I., Neoslavizem in Slovenci, Ljubljana 1994.

Giza A., Neoslawizm i Polacy, Szczecin 1984.

Herman K., Novoslovanstvi a česká buržoasie [w:] Kapitolý z dějin vzájemných vztahů národů ČSR a SSSR, Prague 1958, s. 235-312.

Kawalec K., Roman Dmowski 1864-1939, Wrocław-Warszawa-Kraków 2002.

Višný P., Neoslavism and the Czechs, Cambridge 1984.

Wieczorkiewicz P.P., Udziat Polaków w ruchu neosłowiańskim a stosunki polityczne polsko-rosyjskie 1908-1910, „Pamiętnik Słowiański” 1978, t. 28, s. 133-168.

Лазарова Е., Славянското движение в България, София 1997.

Славянское движение XIX-XX веков: Съезды, конгрессы, совещания, манифесты, обращения, Москва 1998. 